уду 94 (477.8): 329

\title{
ВЗАСМИНИ ЛЕВА БАЧИНСЬКОГО І КИРИЛА ТРИЛЬОВСЬКОГО: ВІД ДІАЛОГУ ДО КОНФРОНТАЦІЇ (кінець ХІХ - перша третина ХХ ст.)
}

\author{
Ганна ПАСКА \\ Державний вищий навчальний заклад \\ "Прикарпатський національний університет імені Василя Стефаника", \\ відділ аспірантури і докторантури, \\ вул. Шевченка, 57, 76018, Івано-Франківськ, Україна \\ e-mail: hannapaska@i.ua \\ DOI: 10.15330/gal.34.117-124 \\ ORCID: 0000-0003-3485-5392
}

\begin{abstract}
Предметом статті є відносини Л. Бачинського і К. Трильовського в руслі украӥнського національно-визвольного руху кіния XIX - першої третини XX ст. Основу джерельної бази дослідження становлять справи фондів ЦДІАЛ України, ЦДАВО України, Держархіву Івано-Франківської обл., автобіографічні праці Л. Бачинського і К. Трильовського та матеріали тогочасної газетної періодики. Методологічною основою статті є принципи об'єктивності, історизму, різноманітності джерельної бази. У роботі використано методи аналізу і синтезу, проблемно-хронологічний, біографічний методи для вивчення життя та діяльності історичної постаті, метод внутрішньої критики джерел. Автор статті приходить до висновку, що взаємини Л. Бачинського і К. Трильовського пройшли шлях від співпраиі та дружніх відносин до відкритих конфліктів і політичної конфронтації. На рубежі XIX-ХХ ст. обидва політики були провідними діячами РУРП-УРП, а в 1907-1918рр. стали послами австрійського парламенту. Початок суперечностей між двома радикалами було покладено після обрання Л. Бачинського головою УРП. Внаслідок загострення протистояння із К. Трильовським у 1910 р. Л. Бачинський змушений був залишити посаду керівника партії. Конфлікт отримав своє продовження в період ЗУНР, коли у 1919 р. К. Трильовський спричинився до розколу УРП та виокремлення із неї власної партії - СРП. Остання фаза протистояння між двома політиками відбулася у ході виборів до польського парламенту в 1928 р., коли з ініціативи К. Трильовського було засновано УСРП-лівиџю. Конфлікт між двома політиками був фактором, який протягом більше двадияти років відігравав негативну, деструктивну роль у радикальній течії західноукраӥнського політикуму.

Ключові слова: Лев Бачинський, Кирило Трильовський, Русько-украӥнська радикальна партія (Украӥнська радикальна партія), Селянсько-радикальна партія, Українська соиіалістично-радикальна партія-лівиия, “Громадський голос".
\end{abstract}

Лев Бачинський (1872-1930рр.) та Кирило Трильовський (1864-1941рр.) - відомі українські громадсько-політичні діячі, активні учасники національно-визвольного руху в Східній Галичині кінця XIX - першої третини XX ст. Їх взаємини відігравали значну роль у партійному житті та суспільних процесах цього періоду та великою мірою впливали на розвиток і діяльність однієї із найбільш впливових українських політичних сил - Української радикальної партії (далі - УРП).

Метою статті є комплексний аналіз відносин Л. Бачинського і К. Трильовського в руслі українського національно-визвольного руху кінця XIX - першої третини XX ст. Досягнення мети передбачає вирішення наступних завдань: 3'ясувати причини конфлікту між Л. Бачинським і К. Трильовським на початку XX ст.; простежити загострення конфронтації між обома радикалами у період Західно-Української Народної Республіки (далі - ЗУНР) і в 1920-ті рр. Дана проблема ще на знайшла свого комплексного висвітлення в науковій літературі. Окремі аспекти $з$ досліджуваної проблеми розкрито у працях Л. Бойчук, А. Міщука і М. Міщук, М. Петpiва, Б. Тищика, В. Яремчука, Р. Томчика (R. Tomczyka) та ін. Основу джерельної бази дослідження становлять справи фондів Центрального державного історичного архіву України у м. Львів, Центрального державного архіву вищих органів влади та управління України, Державного архіву Івано-Франківської області, автобіографічні праці Л. Бачинського і К. Три- 
льовського, матеріали тогочасної газетної періодики (часописи і журнали “Громадський голос", “Хлібороб”, “Зоря”, “Свобода”, “Діло”, “Правда” тощо).

Кирило Трильовський у 1890 р. був одним із співзасновників першої на західноукраїнських землях політичної партії - Русько-української радикальної партії (далі - РУРП), а Л. Бачинський був обраний іiі членом у жовтні 1898 р. Перші документально підтверджені контакти між діячами датуються 1895 роком. Зокрема, 9 червня цього року обидва політики були присутні на третіх загальних зборах українського радикального політичного товариства "Народна Воля" у м. Коломия (створеного у 1893 р.)․․ Однак не виключено, що їхнє знайомство могло відбутися значно раніше. У своїй автобіографії К. Трильовський зазначав, що Л. Бачинський "у своїх молодих літах" довгий час перебував під його впливом². У травні 1900 р. Л. Бачинський був присутній під час заснування К. Трильовським першого українського пожежногімнастичного товариства “Січ” в с. Завалля Снятинського повіту”.

Шостого жовтня 1900 р. Л. Бачинський, К. Трильовський та інші члени РУРП увійшли до створеного в ході народного віча у м. Львів "Краєвого хлопського виборчого комітету". Його завдання полягало у розробці передвиборчої програми РУРП та узгодження кандидатів на послів до австрійського парламенту ${ }^{4}$.

На початку 1901 р. відбувся конфлікт між головним проводом РУРП та К. Трильовським. Редакція часопису РУРП “Громадський голос" відмовилася надрукувати статтю авторства К. Трильовського, який у знак протесту заявив про свій намір вийти зі складу партії. У цій ситуації Л. Бачинський, будучи противником будь яких непорозумінь в середовищі РУРП, звернувся листом від 4 травня 1901 р. до одного із лідерів радикалів та редактора партійного органу Михайла Павлика із проханням мирно врегулювати цей конфлікт. Він вказував на особливі заслуги К. Трильовського у розгортанні радикального руху в галицькому суспільстві та просив дозволити йому опублікувати свою статтю, “тим більше, що він... підписує свої дописи повним іменем і певне перебрав би на себе і відповідальність за них”. Л. Бачинський стверджував, що написав листа до К. Трильовського, в якому намагався “його утихомирити”. Також політик висловив ініціативу скликати партійний з’їзд для обговорення цієї ситуації5. Невідомо, якою була відповідь М. Павлика на лист Л. Бачинського. Проте, уже в наступному листі від 14 травня цього року останній писав М. Павлику: “Сердечно дякую за вияснення. Гадав, що Др. Т. [К. Трильовський] мав важніщі поводи до своїх прозьб, а так дивуюсь як можна було задля невідповідної дописи робити заколот...”.

Четвертого грудня 1905 р під час роботи щорічного з’їзду РУРП у м. Львів Л. Бачинського було обрано головою партії. Цілком імовірно, що ця подія негативно відобразилася на взаємовідносинах Л. Бачинського і К. Трильовського та стала однією з причин майбутніх суперечностей між цими політиками. Також на з’їзді було вирішено остаточно відмовитися від вживання слова “руський” у назві партії і надалі використовувати назву Українська радикальна партія”.

У 1907 i 1911 pр. обидва радикали двічі були обрані послами до австрійського парламенту від УРП. Внаслідок участі обох радикалів у передвиборчій кампанії 1907 р. на друге місце відійшли непорозуміння між ними. Після обрання Л. Бачинського і К. Трильовського

\footnotetext{
${ }^{1}$ Віче і загальні збори “Народноі Волі”. Хлібороб. 1895. Ч. 10-12. С. 1-3.

2 Трильовський К. 3 мого життя. Київ ; Едмонтон ; Торонто, 1999. С. 105.

3 Петрів М. Українські адвокати: державні, громадські, політичні та культурно-освітні діячі кінці XIX першої половини ХХ ст. Кн. 1. Київ : Юстініан, 2002. С. 26; Центральний державний історичний архів України, м. Львів (далі- ЦДІАЛ України). Ф. 309: Наукове товариство ім. Шевченка, м. Львів. Оп. 1. Спр. 2177: Автобіографія члена віце-президента галицької Української Національної Ради Бачинського Лева. Арк. 2.

${ }^{4}$ Парламент руських хлопів. Громадський голос. 1900. Ч. 22. С. 185-186.

5 ЦДІАЛ України. Ф. 663: Михайло Павлик- український письменник і громадський діяч. Оп. 1. Спр. 207: Листи Павлику від кореспондентів з прізвищами на “Ба” - “Би”, 1880-1914 рр. Арк. 59-60 зв.

${ }^{6}$ ЦДІАЛ України. Ф. 663. Оп. 1. Спр. 207. Арк. 61 зв.

7 3’їзд української радикальної партії. Новий громадський голос. 1905. Ч. 34. С. 270-271; Tomczyk R. Radykałowie i socjaldemokraci. Miejsce i rola lewicy w ukraińskim obozie narodowym w Galicji 1890-1914. Szczecin, 2007. S. 323-324.
} 
послами до парламенту обидва політики увійшли до спільного депутатського блоку усіх західноукраїнських політичних партій - Українського парламентського клубу на чолі 3 лідером Української національно-демократичної партії (далі - УНДП) Юліаном Романчуком. Після чергових виборів 1911 р. посли від УРП утворили у парламенті власний Український радикальний клуб під керівництвом радикала Миколи Лагодинського. Його заступником було призначено К. Трильовського, а секретарем - Л. Бачинського. Поряд з цим, не бажаючи розпорошення національних політичних сил, посли від УРП залишилися у складі спільного Українського парламентського союзу разом із представниками від УНДП та Північної Буковини, головою якого був один із визначних членів УНДП Кость Левицький. Під час роботи парламенту обидва радикали виголошували промови та брали активну участь у підготовці інтерпеляцій (звернень) до міністерств Австро-Угорської монархії ${ }^{8}$

Перші значні суперечності між Л. Бачинським і К. Трильовським почалися наприкінці 1908 р. Зокрема, на партійному з'їді УРП 25-26 грудня цього року у м. Тернопіль лідер радикалів вагався чи продовжувати своє головування в УРП через конфлікт із К. Трильовським. На цьому з'їзді було констатовано, що непорозуміння Л. Бачинського із організатором січового руху почалися 3 приводу недисциплінованості останнього, ігнорування ним ухвал і розпоряджень керівництва партії та намагання самому стати головою УРП. Також стверджувалося, що К. Трильовський проводить на Гуцульщині та Покутті власну самостійну політичну лінію, яка не відповідає стратегії радикалів, а з метою поширення серед населення Східної Галичини своїх поглядів та переконань він використовував коломийський двотижневик "Хлопська Правда". Незважаючи на цей конфлікт, Л. Бачинський вирішив і надалі очолювати УРП 9 .

У лютому 1910 р. в січовому місячнику “Зоря” було надруковано статтю під назвою “Сднаймось у “Сїчи”!” написану, імовірно, самим К. Трильовським і спрямовану проти керівника УРП. У ній було констатовано, що під час святкування 31 травня 1909 р. четвертого січового свята у м. Коломия Л. Бачинський (ім'я якого не вказувалося) “ходив 3 понурою головою, зі злобою в оцї, зі страшною завистю в серцї!”. Стосовно нього вживався образливий термін “господин інтригант". Стверджувалося, що “....найгірше пече єго [Л. Бачинського] та популярність, котрою тїшить ся між народом Др. Трильовський”. Лідера радикалів звинувачували у бездіяльності та відсутності будь якої допомоги українським політичним товариствам: “...той чесний інтригантик цїлими десятками лїт не працював не то вже для Сїчей, але хочби для яких инших товариств". Також політику закидали намагання “вирвати ті Сїчі з рук” К. Трильовського. У цій статті було констатовано, що Л. Бачинський “уміє чудесно маскувати ся і удавати дуже тактовного і розважного діяча" 10 .

Публікація цієї статті викликала обурення зі сторони Л. Бачинського, який ініціював скликання партійних нарад задля вирішення цієї справи. Із листа члена УРП Івана Макуха до М. Павлика дізнаємося, що такі засідання “ширшого заряду партії” були призначені на 16 квітня і 8 травня $1910 \mathrm{p}^{11}$.

Цей конфлікт став предметом обговорення на XXI з'їзу УРП, який проходив у м. Львів 18-19 грудня 1910 р. К. Трильовський, який не взяв участі у його роботі, надіслав листа керівництву партії, в якому мотивував свою відсутність через публікацією у газеті "Громадський голос" критичної статті на свою адресу, а також своїм не сприйняттям політичного курсу УРП. У свою чергу Л. Бачинський інформував, що К. Трильовський часто ігнорував ухвали i

\footnotetext{
8 Яремчук В. Українська багатопартійність Наддніпрянської і Західної України : компаративний аналіз (1899-1918 рр.). Київ : ІПіЕНД ім. І. Ф. Кураса НАН України, 2012. С. 262-263; Український радикальний клуб. Громадський голос. 1911. Ч. 35. С. 2.

${ }^{9}$ Tomczyk R. Radykałowie i socjaldemokraci... S. 475; Tomczyk R. Z dziejów ukraińskiego ruchu paramilitarnego w Galicji towarzystwo gimnastyczne i straży ogniowej "Sicz". Przeglad Zachodniopomorski, 2009. T. 24, S. 149.

10 “Сднаймось у “Сїчи”!”. Зоря. 1910. Ч. 1. С. 4-12.

${ }^{11}$ ЦДІАЛ України. Ф. 663. Оп. 1. Спр. 207 Протоколи засідань Української радикальної партії, списки членів, проекти програми, оповістки і виклики на засідання і інші матеріали про діяльність партії, 18941914 рр. Арк. 25-26; Tomczyk R. Z dziejów ukraińskiego ruchu paramilitarnego w Galicji... S. 150.
} 
постанови керівництва партії та “вириває ся з під партійної карности”. Він стверджував, що редакція партійного органу має право друкувати критичні замітки про членів партії. Для врегулювання цього конфлікту з'їзд ухвалив створити комісію із числа прихильників самого К. Трильовського. I як зауважував I. Макух, навіть такий склад комісії не зможе довести жодної провини голови УРП ${ }^{12}$. Однак ці події змусили Л. Бачинського поступитися місцем лідера радикалів на користь М. Лагодинського ${ }^{13}$.

3 початком Першої світової війни 1 серпня 1914 р. К. Трильовський став членом Головної української ради (далі - ГУР), а 6 серпня цього ж року він очолив Бойову управу Українських січових стрільців (УСС $)^{14}$. У травні 1915 р. ГУР було реорганізовано в Загальну українську раду (далі - ЗУР), до складу якої увійшли також Л. Бачинський і К. Трильовський. Зокрема, перший був обраний одним із заступників голови ЗУР К. Левицького ${ }^{15}$. Обидва політики часто перетиналися на засіданнях ЗУР та брали участь у розробці і ухваленні відозв до західноукраїнського населення. Зокрема, з нагоди звільнення австро-німецькою армією Львова від російських військ наприкінці червня 1915 р. ЗУР опублікувала "Відозву до українського народу Галичини і Буковини” від 24 червня цього ж року, під якою залишили свої підписи як Л. Бачинський, так і К. Трильовський ${ }^{16}$.

Загострення конфлікту між Л. Бачинським і К. Трильовським відбулося у період українських національно-визвольних змагань та існування ЗУНР. На початку 1919 р. у середовищі УРП виокремилася опозиційна до офіційного проводу Селянсько-радикальна партія (далі СРП) під керівництвом К. Трильовського, яка звинуватила керівництво УРП у бездіяльності та консерватизмі. СРП ініціювала відновлення видання у м. Коломия часопису "Громадський голос". 14 лютого 1919 р. за сприяння К. Трильовського, Петра Шекерик-Дониківа та Григорія Дувірака в Українській Національній Раді Західної Області Української Народної Республіки (ЗОУНР) було утворено Селянсько-радикальний клуб. Ця фракція виступила за докорінну реорганізації УРП. На конференції СРП, яка відбулася 16 лютого цього ж року у м. Коломия за участі 321 делегата, керівником новоствореної партії було обрано К. Трильовського ${ }^{17}$. Осередки СРП діяли у Коломийському, Богородчанському, Косівському, Печеніжинському та Снятинському повітах. Однак ця партія не мала істотного впливу на партійно-політичне життя Східної Галичини ${ }^{18}$.

Головна управа УРП, зважаючи на такі дії групи К. Трильовського, починаючи з 20 лютого 1919 р. почала видавати у м. Станиславів газету “Народ”. Створення СРП стало предметом обговорення під час з’їзду УРП, який відбувся 22-23 березня 1919 р. у м. Станиславів. В ухвалених резолюціях було прийнято рішення про виключення К. Трильовського із числа членів

\footnotetext{
12 Справозданє з 21. з’їзду української радикальної партії. Громадський голос. 1910. Ч. 52. С. 3.

13 Там само 1910. Ч. 51. С. 2.

14 Петрів М. Українські адвокати... С. 436.

15 Центральний державний архів вищих органів влади та управління Украӥни (далі - ЦДАВО України). Ф. 3807: Жук Андрій (1 липня 1880 р. - 3 вересня 1968 р.) - громадський і політичний діяч, публіцист, діяч українського кооперативного руху, дипломат, дійсний член НТШ. Оп. 2. Спр. 3: Протоколи засідань Загальної Української Ради у м Відні з 1 по 25 засідання (5 травня 1915 - 6 листопада 1916 р. Арк. 1 a; Склад Загальної Української Ради. Свобода. 1915. Ч. 14. С. 1.

${ }^{16}$ ЦДАВО України. Ф. 3807. Оп. 2. Спр. 4: Відозви, меморандуми, повідомлення, листування Головної і Загальної української ради з намісником Австрії, Союзом визволення України з питань війни з Росією, утворення українських військових частин, української адміністрації, запровадження української мови в школах та церквах на окупованих землях австрійською армією, роботи серед полонених українців російської армії в таборах Австрії та інших питань. Статут Українських січових стрільців (14 травня 1914 р. - вересень 1916 р.). Арк. 61.

17 Західно-Українська Народна Республіка 1918-1923: Ілюстрована історія. Львів ; Івано-Франківськ, 2008. С. 217-218; Західно-Українська Народна Республіка. 1918-1923: Історія. Івано-Франківськ : Сіверсія, 2001. С. 233; Тищик Б. Західно-Українська Народна Республіка (1918-1923). Історія держави і права. Львів : Тріада плюс, 2004. С. 249.

18 Міщук А. І., Міщук М. Б. Суспільно-політична діяльність УРП-УСРП на Покутті. Прикарпатський вісник НТШ. Думка. 2017. № 5-6. С. 172.
} 
партії. Також було заборонено самочинне видання часопису “Громадський голос"19. Під час роботи цього з'їзду Л. Бачинського знову було обрано керівником партії ${ }^{20}$.

Після польської окупації Східної Галичини УРП на деякий час припинила свою діяльність, яку стараннями Л. Бачинського було відновлено лише на початку листопада $1920 \mathrm{p.}^{21}$. Сам К. Трильовський у 1920 р. виїхав до м. Відень. У січні - квітні 1921 р. він як представник СРП входив до складу координаційного органу українських політичних сил на еміграції Виконавчого комітету Всеукраїнської національної ради ${ }^{22}$. Перебуваючи за кордоном, К. Трильовський був ініціатором та упорядником брошури “Запорожець. Календар на рік звичайний 1921”. За його сприяння тут було надруковано агітаційну статтю під псевдонімом “Іван С.” (імовірно Іван Сандуляк) спрямовану як проти самого Л. Бачинського, так і проти УРП в цілому. Автор закликав читачів вступати до лав СРП, оскільки, як він твердив, ця партії є “спадкоємницею давньої, славної, під подихом духа Драгоманова... радикальної партії'. Створення К. Трильовським опозиційної СРП обгрунтовувалося нібито прагненням Л. Бачинського ще в серпні 1918 р. ліквідувати УРП. У цій брошурі критикувалися політичні дії лідера радикалів, а його головування у партії визнавалося тільки як “сумна дійсність”. Було констатовано, що УРП під його керівництвом $€$ “лише насміхом над всяким радикалізмом”. Також тут стверджувалося, що Л. Бачинський нібито був противником злуки ЗУНР з Українською Народною Республікою (УНР) 1919 р. та виступав на захист греко-католицької церкви, що вважалося неприпустимим для радикала. Далі зауважувалося, що 22 січня 1919 р. “лучився факт майже неімовірний: той самий пан Лев Бачинський, що так гремів на Нац. Раді проти злуки з Великою Україною, поїхав до Києва..., де виголосив на святі злуки обох Україн... горячу промову - славячу злуку всієї України!”. Автор статті звинувачував І. Макуха, “чоловіка... твердої праці”, у тому, що він потрапивши під сильний вплив Л. Бачинського, виконує усі його доручення і вказівки ${ }^{23}$.

На початку 1920-х рр. керівництво УРП на чолі з Л. Бачинським з метою посилення своїх політичних позицій та задля консолідації Східної Галичини і Волині в умовах польської окупації, вело переговори з Українською партією соціалістів-революціонерів (УПСР) про ії зближення із УРП ${ }^{24}$. Зрештою, 24 січня 1926 р. у м. Кременці на з'їзді волинських есерів було вирішено об'єднатися із галицькими радикалами в єдину партію. Офіційне об'єднання УРП з УПСР в Українську соціалістично-радикальну партію (далі - УСРП) відбулося 14 лютого 1926 р. у м. Львів, а головою новоствореної партії обрано Л. Бачинського ${ }^{25}$.

У 1927 р. в середовищі УСРП почали спостерігатися деякі деструктивні процеси, які були спричинені поверненням з еміграції К. Трильовського та заснування ним 1 січня 1928 р. власної Української соціалістично-радикальної партії-лівиці (УСРП-лівиці). Новостворена партія виступила за об'єднання західноукраїнських земель із Радянською Україною. Однак вплив партії К. Крильовського на населення краю був незначним ${ }^{26}$.

У відповідь на намагання К. Трильовським організувати власну партію голова УСРП Л. Бачинський на повітовій конференції, яка відбулася 1 січня 1928 р. в с. Устя на Снятинщині,

\footnotetext{
19 Зїзд української радикальної партії в Станиславові. Новини. 1919. Ч. 12. С. 1-2; Західно-Українська Народна Республіка 1918-1923: Ілюстрована історія... С. 218.

20 Західно-Українська Народна Республіка. 1918-1923: Історія... С. 235.

${ }^{21}$ Міщук А. І., Міщук М. Б. Суспільно-політична діяльність УРП-УСРП на Покутті... С. 172-173.

22 Петрів М. Українські адвокати... С. 437.

${ }^{23}$ Питання на часі. Календар "Запорожещь” на рік звичайний 1921. Відень, 1920. С. 76-80.

243 партійного життя. Громадський голос. 1925. Ч. 40. С. 3.

25 Державний архів Івано-Франківської області (далі - Держархів Івано-Франківської обл.). Ф. 2: Станиславівське воєводське управління, м. Станиславів. Оп. 1. Спр. 415: Місячні звіти повітових староств про політичну ситуацію в Станиславівському воєводстві за січень - березень 1926 р. Арк. 205; Держархів Івано-Франківської обл. Ф. 6: Станиславівське повітове староство, м. Станиславів. Оп. 1. Спр. 168: Місячні звіти Станиславівського повітового управління поліції про політичну ситуацію в повіті за 1926 р. Арк. 36; 3'їзд Української Соціалістично-Радикальної Партії. Громадський голос. 1926. Ч. 7. С. 4-5.

${ }^{26}$ Міщук А. І., Міщук М. Б. Суспільно-політична діяльність УРП-УСРП на Покутті... С. 176.
} 
виступив із різкою критикою таких дій. Політик стверджував, що повернення до краю К. Трильовського і створення ним власної партії призведе до розколу в УСРП ${ }^{27}$.

Газета "Правда" за 8 січня 1928 р. $з$ цього приводу писала: "Немає сумніву, що він [К. Трильовський] перетягне до своєї “лівиці” багато членів соціялістично-радикальної партії, передусім в Коломийщині, де д-р Трильовський ще до війни мав великий вплив як організатор "Січей" 28.9 січня цього ж року у м. Станиславові в редакції газети "Громадські вісті" відбувся з’їзд УСРП-лівиці. У своєму виступі К. Трильовський заявив, що повернувся до краю через поширення чуток про намір Л. Бачинського зблизитися із Українським національно-демократичним об'єднанням (далі - УНДО) ${ }^{29}$.

На сторінках часопису УСРП “Громадський голос” лунала критика на адресу К. Трильовського зі сторони його колишніх однопартійців. Його звинувачували у лояльному ставленні до поляків та намаганні взяти участь у виборах до польського парламенту 1928 р. Політика засуджували за те, що повернувся до краю тільки після припинення масових арештів серед українців польською владою. Хвиля невдоволення, спричинена поверненням К. Трильовського в Східну Галичину і заснуванням ним УСРП-лівиці, змусила його зняти свою кандидатуру в ході парламентських виборів до польського парламенту. Після цього діяльність УСРП-лівиці була припинена. Своє ставлення до цих подій К. Трильовський висловив у листі до Осипа Назарука стверджуючи, що “страшний перелом в душі моїй зробили... кальомнії, які накинули на мене радикали (Стахів, Левко) [Матвій Стахів, Л. Бачинський]... Це мене страшно зломило...” Тільки після смерті Л. Бачинського (11 квітня 1930 р.) К. Трильовський 27 вересня 1930 р. знову зміг стати членом УСРП ${ }^{30}$.

В офіційному органі УНДО, газеті “Діло” у квітні 1930 р. у некролозі Л. Бачинського 3 приводу конфлікту двох політиків зазначалося: “був [Л. Бачинський] завсіди ворогом демаroriï.., з тої причини мав пості йно конфлікти зі своїм партійним товаришем д-ром К. Трильовським, 3 яким остаточно таки зовсім розійшовся"з1.

Отже, взаємини Л. Бачинського і К. Трильовського пройшли шлях від співпраці та дружніх відносин до відкритих конфліктів і політичної конфронтації. На рубежі XIX-XX ст. обидва політики були провідними діячами РУРП-УРП, брали участь у партійних з'їздах, зборах товариства “Народна Воля”, а в 1907-1918 рр. були послами до австрійського парламенту. На початку XX ст. Л. Бачинський намагався вплинути на конфлікт К. Трильовського з редакцією газети "Громадський голос" та не допустити виходу останнього із лав партії. Початок суперечностей між двома радикалами було покладено після обрання Л. Бачинського головою УРП. Саме внаслідок загострення конфлікту із К. Трильовським у 1910 р. Л. Бачинський змушений був залишити посаду керівника партії. У період Першої світової війни було відчутнім деяке послаблення напруженості у їхніх відносинах. Проте конфлікт отримав своє продовження в період ЗУНР, коли у 1919 р. К. Трильовський спричинився до розколу УРП та виокремлення із неї власної партії - СРП. Бажаючи підірвати авторитет УРП у галицькому суспільстві, він ініціював публікацію статей спрямованих проти Л. Бачинського. Остання фаза конфлікту між двома політиками відбулася у ході виборів до польського парламенту в 1928 р., коли 3 ініціативи К. Трильовського було засновано УСРП-лівицю, яка створила певну конкуренцію УСРП під головуванням Л. Бачинського. Конфлікт між двома політиками був фактором, який протягом більше двадцяти років відігравав негативну, деструктивну роль у радикальній течії західноукраїнського політикуму.

\footnotetext{
27 Український національно-визвольний рух на Прикарпатті в XX столітті. Документи і матеріали. Т. 1. Кн. 1: 1919-1929. Івано-Франківськ : ЛІК, 2012. С. 507.

${ }^{28}$ Наші партії. Правда. 1928. Ч. 1-2. С. 12.

29 Держархів Івано-Франківської обл. Ф. 2. Оп. 1. Спр. 556: Переписка 3 повітовими староствами про передвиборчу кампанію націоналістичних партій на території Станиславівського воєводства у зв'язку 3 виборами у польський парламент (1 лютого 1927 р. - 2 березня 1928 р.). Арк. 40.

${ }^{30}$ Бойчук Л. Суспільно-політична діяльність К. Трильовського (середина 1920-х - 1930-х рр.). Схід. 2013. № 1 (121). C. 64. DOI: https://doi.org/10.21847/1728-9343.2013.1(121).13419.

31 Д-р Лев Бачинський. Життя й діяльність провідника соц.-радикальної партії. Діло. 1930. Ч. 86. С. 3.
} 
Перспективним напрямом подальшого наукового пошуку є детальне дослідження питання взаємин Л. Бачинського із К. Трильовським у період Першої світової війни. Також потребує вивчення тема взаємовідносин Л. Бачинського із представниками політичної еліти Східної Галичини в означуваний період.

\title{
THE RELATIONSHIP BETWEEN LEW BACHYNSKY AND KYRYLO TRYLYOVSKY: FROM DIALOGUE TO CONFRONTATION (LATE OF 19th - FIRST THIRD OF 20th CENTURY)
}

\author{
Hanna PASKA \\ State Higher Educational Institution \\ "Vasyl' Stefanyk Precarpathian National University", \\ Postgraduate by specialty 032 "History and Archeology", \\ Shevchenko St., 57, 76018, Ivano-Frankivsk, Ukraine \\ e-mail: hannapaska@i.ua
}

\begin{abstract}
Summary
The subject of the article is the relations between Lew Bachynsky and Kyrylo Trylovsky in the context of the Ukrainian national liberation movement of the late 19th and first third of the 20th century. The source base of the research is based on the funds of the Central State Historical Archive of Ukraine (Lviv), the Central State Archive of the Highest Authorities of Ukraine (Kyiv), the State Archive of Ivano-Frankivsk region, the autobiographical works of L. Bachynsky and K. Trylovsky and materials of contemporary newspaper periodicals. The methodological basis of the article is the principles of objectivity, historicism, diversity of the source base. The methods of analysis and synthesis, problem-chronological, biographical methods for studying the life and activity of a historical figure, the method of internal critique of sources are used in the work. The author of the article concludes that the relationship between L. Bachynsky and K. Trylovsky went from cooperation and friendly relations to open conflicts and political confrontation. At the turn of the 19th and 20th centuries both politicians were leading figures of the Ruthenian-Ukrainian Radical Party (RURP) - Ukrainian Radical Party (URP), and in 1907-1918 became deputies of the Austrian parliament. In the early 20th century L. Bachynsky tried to influence K. Trylovsky's conflict with the office of the "Hromadsky Holos" newspaper and prevent the him from withdrawal from the party. The controversy between the two radicals began after $L$. Bachynsky became chairman of the URP. As a result of the escalation of the conflict with K. Trylovsky in 1910, L. Bachynsky was forced to resign as party leader. During the First World War, there was some easing of tensions in their relationship. However, the conflict continued during the period of Western Ukrainian People's Republic, when in 1919 K. Trylovsky split the URP and separated its own party, the Peasant-Radical Party. The last phase of the conflict between the two politicians took place during the elections to the Polish Parliament in 1928, when the Ukrainian Socialist-Radical Party "the Left" was founded on the initiative of K. Trylowski. The conflict between the two politicians was a factor that for more than twenty years played a negative, destructive role in the radical current of Western Ukrainian politics.
\end{abstract}

Keywords: Lev Bachynsky, Kyrylo Trylovsky, Russian-Ukrainian Radical Party (Ukrainian Radical Party), Peasant-Radical Party, Ukrainian Socialist-Radical Party "The Left", "Hromadsky Holos".

\section{REFERENCES}

Boichuk, L. (2013). Suspilno-politychna diialnist K. Trylovskoho (seredyna 1920-kh - 1930-kh rr.) [Socio-Political Activity of K. Trylovsky (mid 1920s - 1930s)]. Skhid, 121(1), pp. 63-67. Doi: https://doi.org/ 10.21847/1728-9343.2013.1(121).13419 (in Ukrainian). Ukrainian).

D-r Lev Bachynskyi. Zhyttia y diialnist providnyka sots.-radykalnoi partii. (1930). Dilo, no. 86 (in

"Iednaimos u "Sichy"!". (1910). Zoria, 1 (in Ukrainian).

Karpenko, O. (Ed.) (2001). Zakhidno-Ukrainska Narodna Respublika. 1918-1923: Istoriia [Western Ukrainian People's Republic 1918-1923: History]. Ivano-Frankivsk: Siversiia (in Ukrainian).

Kuhutiak, M. (Ed.) (2008). Zakhidno-Ukrainska Narodna Respublika 1918-1923: Iliustrovana istoriia. [Western Ukrainian People's Republic 1918-1923: Illustrated History]. Lviv; Ivano-Frankivsk: ManuskryptLviv (in Ukrainian).

Kuhutiak, M. (Ed.) (2012). Ukrainskyi natsionalno-vyzvolnyi rukh na Prykarpatti v XX stolitti. Dokumenty i materialy. T. 1. Kn. 1: 1919-1929 [Ukrainian National Liberation Movement in Prykarpattia in the Twentieth Century. Documents and Materials. Vol. 1. Pt. 1 (1919-1929)]. Ivano-Frankivsk: LIK (in Ukrainian). 


\section{Галичина}

Mishchuk, A. I., Mishchuk, M. B. (2017). Suspilno-politychna diialnist URP-USRP na Pokutti [SocioPolitical Activity of the URP-USRP in Pokuttia]. Prykarpatskyi visnyk NTSh. Dumka, no. 5-6, pp. 170-180 (in Ukrainian).

Nashi partii. (1928). Pravda, no. 1-2 (in Ukrainian).

Parlament ruskykh khlopiv. (1900). Hromadskyi holos, 22 (in Ukrainian).

Petriv, M. (2002). Ukrainski advokaty: derzhavni, hromadski, politychni ta kulturno-osvitni diiachi kintsi XIX - pershoi polovyny XX st. Kn. 1 [Ukrainian Lawyers: State, Public, Political and Cultural-Educational Figures of the End of the XIX - First Half of the XX Century. Vol. 1]. Kyiv: Yustinian (in Ukrainian).

Pytannia na chasi. (1920). Kalendar "Zaporozhets" na rik zvychainyi 1921. Viden (in Ukrainian).

Spravozdanie z 21. zizdu ukrainskoi radykalnoi partii. (1910). Hromadskyi holos, 51 (in Ukrainian).

Spravozdanie z 21. zizdu ukrainskoi radykalnoi partii. (1910). Hromadskyi holos, 52 (in Ukrainian).

Tomczyk, R. (2007). Radykałowie i socjaldemokraci. Miejsce i rola lewicy w ukrainskim obozie narodowym w Galicji 1890-1914 [Radicals and Social Democrats. The Place and Role of the Left in the Ukrainian National Camp in Galicia 1890-1914]. Szczecin (in Polish).

Tomczyk, R. (2009). Z dziejów ukraińskiego ruchu paramilitarnego w Galicji towarzystwo gimnastyczne i straży ogniowej "Sicz" [From the History of the Ukrainian Paramilitary Movement in Galicia, the "Sich" Gymnastic and Fire Brigade Society]. Przegląd Zachodniopomorski, 24, pp. 149-150 (in Polish).

Trylovskyi, K. (1999). Z moho zhyttia [From My Life]. Kyiv; Edmonton; Toronto (in Ukrainian).

Tyshchyk, B. (2004). Zakhidno-Ukrainska Narodna Respublika (1918-1923). Istoriia derzhavy i prava. [Western Ukrainian People's Republic (1918-1923). History of State and Law]. Lviv: Triada plius (in Ukrainian).

Ukrainskyi radykalnyi klub. (1911). Hromadskyi holos, 35 (in Ukrainian).

Viche i zahalni zbory "Narodnoi Voli". (1895). Khliborob, 10-12 (in Ukrainian).

Yaremchuk, V. (2012). Ukrainska bahatopartiinist Naddniprianskoi i Zakhidnoi Ukrainy: komparatyvnyi analiz (1899-1918 rr.) [Ukrainian Multiparty System of Dnieper and Western Ukraine: a Comparative Analysis (1899-1918)]. Kyiv: IPiEND im. I. F. Kurasa NAN Ukrainy (in Ukrainian).

Z partiinoho zhyttia. (1925). Hromadskyi holos, 40 (in Ukrainian).

Zizd ukrainskoi radykalnoi partii v Stanyslavovi. (1919). Novyny, 12 (in Ukrainian).

Zizd ukrainskoi radykalnoi partii. (1905). Novyi hromadskyi holos, 34 (in Ukrainian).

Zizd Ukrainskoi Sotsialistychno-Radykalnoi Partii. (1926). Hromadskyi holos, 7 (in Ukrainian). 